Ивана Мали

Филолошки факултет

Универзитет у Београду
UDC: $811.411 .21: 004$

DOI: $10.18485 /$ dh.2015.2.ch21

\title{
НЕКИ ПРОБЛЕМИ ЛОКАЛИЗАЦИЈЕ СОФТВЕРА НА АРАПСКИ
}

\section{Сажетак}

Локализација је термин који се односи на прилагођавање производа одређеном тржишту. Овај рад се бави локализацијом софтверских производа намењених тржиштима арапских земаља. Процес локализације не укључује само превођење софтверског дискурса на арапски, него и одређени степен техничке и културне адаптације. У раду ће бити размотрене специфичности арапског језика и културе, које долазе до изражаја у овом процесу.

Кључне речи: арапски језик, локализација софтвера, превођење, софтверска терминологија, арапска култура, арапско писмо

\section{Настанак и развој локализације}

Све до раних 80-их година употреба рачунара била је повезана са познавањем енглеског језика, јер су сви постојећи програми и оперативни системи користили енглеску терминологију, а прве софтверске фирме потекле су са енглеског говорног подручја. Након што су поменуте фирме отпочеле продају својих производа на страним тржиштима, увидело се да ће њихов профит бити знатно већи, уколико се производи језички и културолошки прилагоде локалним тржиштима. Овај процес адаптације производа назива се локализација. (Corbolante and Irmler 516; Mazur 146; Schäler 197; Sin-Wai 348) Упоредо са развојем врло профитабилног и конкурентног тржишта софтерских производа, на ком се иновације свакодневно појављују, развијала се и индустрија локализације. Вишејезични програми, који олакшавају употребу рачунара ван енглеског говорног подручја, више нису реткост, што доприноси повећању броја 
корисника компјутерске технологије у свету. Данас локализација представља готово неизоставну фазу у развоју софтвера, као и пратећих материјала (попут документације или онлајн помоћи за употребу софтвера). Велике софтверске фирме имају своје стручњаке за локализацију, а многе од њих овај посао препуштају агенцијама које се баве локализацијом и/или превођењем. Поред тога, користе се и онлајн алати за превођење, а све је значајнија улога непрофесионалних преводилаца, који се обично бесплатно укључују у различите пројекте локализације, доступне на вебу. (Sin-Wai 360)

\section{Значај локализације}

Захваљујући развоју индустрије локализације, можемо констатовати да енглески језик губи статус lingua franca у виртуелном свету, док се удео других језика повећава. Локализација је уско повезана са радом на терминологији, па превођење софтвера пружа прилику за творбу и дисеминацију компјутерске терминологије и на другим језицима. Значај локализације види се и по све већем броју истраживања и конференција посвећених овој теми, као и по томе што се курсеви из ове области оснивају при различитим образовним институцијама. Тренутно се већина радова посвећених локализацији бави њеним комерцијалним аспектом, док се знатно мањи број радова бави локализацијом као делом примењене лингвистике. Локализација је још увек прилично запостављена у традуктологији, па не постоје адекватне теоријско-методолошке основе, на којима би се заснивала даља истраживања. Стога, Jiménez-Crespo закључује да, из академског угла, локализација тек треба да добије пажњу коју заслужује. (Jiménez-Crespo 1; Mazur 163; Sin-Wai 360).

\section{Локализација у ширем смислу}

Иако се локализација често поистовећује са превођењем, она укључује и одређени степен адаптације материјала који се преводи. Због тога је можемо одредити као „превођење у ширем смислу“. У контексту локализације, о култури се говори као о „тржишту“, 
док се текстови посматрају као „производи“. То значи да је, поред језичких, потребно размотрити и различите техничке, културолошке и маркетиншке аспекте, имајући у виду особености тржишта којем је софтвер намењен. На пример, код класичног превођења не треба да конвертујемо долар у неку арапску валуту, нити да датум по соларном календару прилагодимо лунарном, док је код локализације то пожељно или непоходно. Schäler истиче да превођење није нужно повезано са дигиталним материјалом, док локализација јесте. Поред текста, који је предмет класичног превођења, локализација може да обухвати и графику, аудио и видео материјал и сл. (Brooks 44; Corbolante and Irmler 517-518; Schäler 196; Sin-Wai 360)

У софтверској индустрији, превођење и локализација чине део ширег процеса, који се назива акронимом ГИЛт (енг. GILT-Globalization, Internationalization, Localization and Translation). Први корак у овом процесу, глобализација, односи се на пословне стратегије које имају за циљ да производ учине глобалним, те да га прилагоде корисницима широм света, без обзира на језик, државу и културу којој припадају. (Esselink 4; Jiménez-Crespo 25; Schäler 196) Глобализација обухвата интернационализацију и локализацију производа са превођењем. Интернационализовати производ значи учинити га језички и културно неутралним, да би се потом могао локализовати за било које тржиште, без додатних проблема и измена, уз што мање трошкове. Добро интернационализован софтверски производ подржава различита писма, различите распореде слова на тастатури, валуте и формате приказивања датума и времена и сл. Интернационализација се врши у првим фазама развоја софтвера, пре почетка локализације. (Esselink 25; Jiménez-Crespo 25; Schäler 196; Sin-Wai 348)

\section{Интернационализација за арапско тржиште}

Једно од достигнућа интернационализације, које је олакшало локализацију софтвера за арапско тржиште, јесте увођење Уникода (енг. Unicode), индустријског стандарда за доследно енкодовање, приказ и руковање текстом из већине светских писама. Уникод подржава сва постојећа писма, тако да је немогуће да неки карактер 
буде погрешно приказан. (Esselink 26) Пре појаве Уникода, није било могуће комбиновати арапско писмо са другим писмима у истом документу, док у ранијој фази развоја компјутерске технологије уопште није било могуће писати арапским писмом. Данас већина софтверских производа подржава Уникод, што је потпомогло локализацију за арапска тржишта.

Поред функционалности, у процесу интернационализације, пажња се поклања и изгледу корисничког интерфејса софтвера. Арапски језик се пише са десна на лево, па интерфејс намењен арапском тржишту треба да изгледа као одраз у огледалу енглеске верзије. То значи да ће, поред текста, и већина елемената графичког корисничког интерфејса бити оријентисана са десна на лево, попут навигационог менија, графичких приказа дугмића, траке за померање видљивог дела екрана, поља за унос текста и сл. Уколико је текст софтвера преведен на арапски, а интерфејс није оријентисан са десна на лево, то корисницима може представљати потешкоћу у употреби овог софтвера. (DiFranco 66) У неким случајевима, јавиће се потреба за двосмерним текстом, пошто се неки елементи не могу локализовати. Веб сајтови, адресе електронске поште, као и различите програмерске команде и упутства не могу се превести на арапски. Неретко акроними и називи производа и фирми остају непреведени. 3бог тога ће се на неким местима појавити двосмерни текст, у ком се комбинује арапско и латинично писмо. У задатак интернационализације спада и решавање оваквих типографских проблема, како би текст био правилно приказан у коначном производу.

\section{Локализација за арапско тржиште}

Култура и локалне конвенције

У контексту локализације, важно је разграничити појам „локала“, који представља спој језика и културе на одређеном подручју. Прецизније, локал је спој одређеног језичког варијетета и локалних конвенција које се тичу валуте, подешавања датума и времена, приказивања бројева, симбола и сл. (Руm 2) Стога, неки производи нису локализовани за цело арапско тржиште, него за одређену државу или регион. Постоји мноштво конвенција и формата за 
приказивање датума и времена у свету. Наведени примери из оперативног система Windows 7 показују различита подешавања за датуме и време, за различите локале унутар арапског света: у арапским земљама за месеце у години постоји више назива. За месец август у УAE се користи назив ag்usțus, у Мароку ġust, у Алжиру ūt, у Либану $\bar{a} b$, док у Саудијској Арабији важи муслимански календар - у августу 2015. године он се поклопио са месецом Зу-л-ка'dе, 1436. године. У овим земљама постоје и разлике у форматима приказивања датума

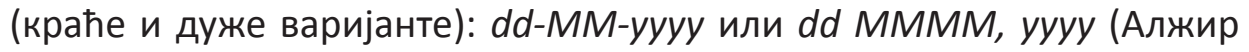
и Мароко), dd/MM/уу или dd/MМММ/уууу (Саудијска Арабија) и dd/ ММ/уууу или dd MМММ, уууу (УАЕ и Либан). Почетком седмице у Алжиру и УАЕ сматра се субота, док је у Либану и Мароку то понедељак, а у Саудијској Арабији недеља. Што се тиче цифара, у подешавањима оперативног система Windows 7, цифре 0,1,2,3,4,5,6,7,8 и 9 се користе у Алжиру и Мароку, док се за остала три локала користе цифре $\bullet, 1, r, r, \xi, \bullet,\ulcorner, \vee, \wedge$ и 9 .

Интернационализован софтверски производ, који је лишен било каквих елемената културе, може се прилагодити циљном тржишту, тако да корисник не осећа производ као стран. Пожељно је да се начин обраћања производа кориснику прилагоди локалном менталитету и културним конвенцијама. На пример, превод текста са енглеског, који садржи дугачке и експлицитне поруке, можда неће одговарати арапском кориснику софтвера. Арапска култура се убраја утзв. „културе високог контекста“, у којима се значења порука налазе, како у самој поруци, тако и у контексту. Стога је већина информација изведена из контекста поруке, док се мање информација експлицитно преноси. Арапској култури неће бити битна само папирологија, нити чињенице. Дугачки уговори, документација и техничке напомене треба избегавати, када је у питању ово тржиште. Препоручује се да се они замене графицима или сликама. (Singh 174)

Што се тиче обраћања корисника производу, занимљива препорука долази из фирме Microsoft - приликом локализације треба избегавати обраћање рачунару као да је живо биће, јер то није прихватљиво у арапском језику. (Arabic Style Guide 32)

Фактор политичке коректности је такође значајан у процесу локализације. Када су у питању државне границе, топоними или за- 
ставе, некада је немогуће бити неутралан, али се производ може прилагодити одређеном тржишту, уз избегавање података који би могли повредити нечија осећања. На пример, ако је производ намењен арапском тржишту, не би у њему требало наводити топоним „Персијски залив“, него „Арапски залив“. (Singh 15) Мапе, заставе, фотографије, топоними, лингвоними, историјски или политички подаци, религијски и други симболи су неки од главних аспеката о којима треба водити рачуна у процесу локализације.

Када је реч о религији, више пута се догодило то да неки софтверски производ садржи материјал који муслимани сматрају увредљивим и богохулним. У најпознатије примере за то спада борбена видео игра Kakuto Chojin. Једна од музичких тема која се нашла у овој игри је део из Курана. Иако је овај пропуст примећен непосредно пре пуштања игре у продају, а проблематични део уклоњен, на тржишту САД нашла се првобитна верзија. Убрзо је ова верзија дошла и до арапског света, па је забрањена у Саудијској Арабији и у још неким муслиманским земљама. После извесног времена, игра је у целом свету повучена из продаје, што је био велики финансијски губитак за њеног произвођача, фирму Microsoft. (Bernal-Merino 103; Maxwell Chandler and O'Malley Deming 19)

Избор боја такође може бити битан, јер оне у различитим културама имају различита значења. Зелена боја, на пример, у САД може да буде симбол животне средине, новца или зависти. Иста боја је национална боја Ирске и у овој земљи означава католичанство и национализам. У арапским земљама она означава светост - то је света боја ислама. (Yunker 485)

Исто важи и за многе друге симболе. Данас је већина корисничких интерфејса софтвера графички оријентисана, што значи да су многе команде представљене иконама или дугмићима са одређеним симболима. Ти симболи могу имати различита значења у различитим културама. Овим визуелним представама обично се не баве преводиоци нити познаваоци страних култура, па се може десити пропуст, због кога ће одређени симболи представљати увреду у некој култури. Због тога им треба посветити посебну пажњу у процесу локализације. 


\section{Превођење терминологије}

Мало је области које су у последње три деценије имале тако буран развој као што је то случај са софтверском индустријом. Данас нови софтверски прозводи настају готово свакодневно, а пратећи овај развој, терминологија се креће у правцу даље дивергенције. Све је више појмова које треба именовати на енглеском и наћи за њих еквиваленте на другим језицима. 3бог тога је веома тешко дефинисати и ограничити софтверску терминологију. У њен корпус не спадају само термини који се односе на софтвер - ту су и многи хардверски термини који се јављају у софтверском дискурсу. Поред тога, софтверски дискурс укључује и термине из других области, у зависности од намене софтвера, као и речи из општег лексичког фонда.

Компјутерска терминологија чини највећи део софтверског дускурса. Развој и настанак ове терминологије диктира индустрија, па софтверске фирме неретко имају сопствени стил и терминологију, која се разликује од њихових конкурената. (Mazur 146) Често долази до тога да терминологија не буде усаглашена између софтверских фирми. Овај проблем је посебно изражен у арапском језику, пошто се арапска компјутерска терминологија састоји од великог броја терминолошких дублета.

Неки од ових дублета настали су паралелном употребом страних и домаћих термина. Док фирма Microsoft, на пример, инстистира на томе да се термини mouse и computer не преводе на арапски, него да се користе адаптиране позајмљенице (Arabic Style Guide 34), организација Arabeyes, која се бави локализацијом слободног софтвера отвореног кода, има изразито пуристички приступ. У софтверским производима које локализује ова организација налазе се термини fa'ra и hāsūb. Дублетност компјутерске терминологије неретко настаје и паралелном употребом различитих домаћих термина. Рецимо, термин document се може превести као watīqa или као mustanad. Оба термина су употреби, у различитим софтверским производима.

Неретко долази и до употребе једног арапског термина, као превод два или више енглеска термина сличног значења. Термин tahmïl, на пример, служи као превод енглеских термина load, download и 
upload. Meђу производима фирме Microsoft нашли смо следеће примере: термин dag்t служи као превод енглеских термина compress и press, док се термином тu'āliğ преводе термини processor и wizard. Исто тако, термином mash могу превести термини clear и scan. Један од главних разлога за ову појаву је тај што је прво настао један појам, а термин за њега је постао устаљен у употреби. Затим је настао и други појам, за који није било бољег термина, до оног који је већ употребљен за први појам.

Усаглашеност терминологије у различитим софтверским производима или различитим верзијама истог производа постиже се коришћењем преводилачких меморија - база података у којима се чува претходно преведени текст, који преводилац може консултовати у току локализације.

У процесу локализације треба водити рачуна и о конотацијама термина. Термине треба преводити тако да њихово значење буде јасно говорницима арапског језика. Код превођења неких термина који се јављају у софтверском дискурсу, треба размотрити симболичку вредност и фугуративно значење на језику-извору, а потом наћи одговарајући семантички еквивалент на језику-циљу. На пример, термин doughnut chart се односи на графикон који је округао, са рупом у средини, па подсећа на америчке крофне. Имајући у виду то да на арапском говорном подручју ова метафора неће бити схваћена на прави начин, фирма Microsoft је овај термин превела на арапски као „округли, шупљи графикон“ - muhatțaț dā'iriyy muğawwaf.

Уколико је то маркетиншки оправдано, у неким случајевима се може и задржати семантички неадекватан термин, као у апликацији за управљање друштвеним мрежама, названој Hootsuite. Ова апликација носи лого са ликом сове (енг. owl). Термин owl се јавља и у дискурсу овог софтвера, у ком се говори о „мудрој и доброј сови“. То се види су следећим примерима из апликације: You are one wise owl 'anta būm hakim и Upgrade to the full version of Hootsuite to gain access to more owl goodness! qum bi al-tarqiyya ilā al-nusha al-kāmila min HootSuite li tatamatta'a bi hiyārāt akțar. За разлику од западноевропског културног круга, у ком сова симболише мудрост, у арапском свету ова реч има негативне конотације, јер сова представља лош знак. 


\section{Одсуство контекста}

Једна од главних разлика између традиоционалног начина превођења текста и превођења софтверског дискурса је одсуство контекста. За разлику од текста, софтверски дискурс је нелинеаран. Његово превођење врши се у неком од алата за локализацију, који преводиоцу приказују мање делове текста, зване стрингови (енг. strings). Један стринг обично садржи једну команду, реченицу, једну смислену целину. Будући да преводилац понекад не зна где ће се и у ком контексту користити одређени стринг, може доћи до погрешних превода. Рецимо, уколико преводилац наиђе на термин index, без контекста у ком се ова реч јавља, он не може поуздано знати да ли она означава неки показатељ - у том случају могла би се превести као mu'aššir - или је у питању неки попис, регистар - у том случају могла би се превести арапским термином fihris.

Одсуство контекста врло често доводи до граматичких недоумица, а понекад и до грешака у коначном производу. Неке парне појмове који су на енглеском језику изражени множином, на арапски би требало преводити двојином, мада то често није случај у софтверским производима. На пример:

The passwords did not match kalimāt al-murūr ġayr mutațābiqa

Brackets around single space al-aqwās al-mawğūda hawla almisāfa al-wāhida

The user name may not contain quotation marks qad lā yahtawī ism al-mustahdim 'alā 'alāmāt al-iqtibās

Речи за појмове који се броје у арапском језику стоје у различитим граматичким облицима, у зависности од бројчане вредности. Иза броја 1 долази једнина, иза 2 двојина, иза бројева 3-10 стоји генитив множине, бројеви 11-99 захтевају акузатив једнине, а иза већих бројева стоји генитив једнине. Када се са енглеског преводе стрингови који садрже неку промењиву бројчану вредност, може доћи до граматичких грешака, као што показују следећи примери:

3 results found $\rightarrow 3$ natīğa mawğ $\bar{d} d a$

2 hours $\rightarrow 2$ sā'āt 
Одређене недоумице и/или граматичке грешке се могу јавити и код категорије рода, с обзиром на разлике између рода у арапском и енглеском, код глагола и личних заменица:

No, remove it $\rightarrow$ Iă, qum bi 'izālatihā / 'izālatihi

Click on the picture below $\rightarrow$ 'iḍgaț / 'iḍgațī 'alā al-șura 'adnāhu

Contains editing commands $\rightarrow$ yaḥtawī / taḥtawī 'alā 'awāmir altahrīr

\{Facebook user\} accepted your friend request $\rightarrow$ wāfaqa / wāfaqat \{Facebook user\} 'alā țalab al-șadāqa

Преводи глагола, којима се изражавају одређене наредбе кориснику или захтеви рачунару од стране корисника, могу бити схваћени двосмислено. Услед одсутва контекста и природе арапског писма у ком се кратки вокали не бележе, неки облици глагола у активу, пасиву или императиву могу изгледати идентично. Овај проблем се у софтверским производима обично решава коришћењем глаголских именица:

Print $\rightarrow$ țibā'a

Search $\rightarrow$ baḥt

Message saved $\rightarrow$ tamma hịz al-risāla

Successfully installed $\rightarrow$ tamma al-tatbit

Change autoversion $\rightarrow$ tag்yïr al-ișdār al-tilqā'yy

Add user to group iḍāfa al-mustahdim 'ilā al-mağmū'a

Delete all selected messages? $\rightarrow$ hadf al-rasā'il al-muhaddada kullihā?

Log off, switch user, lock screen or power down the computer $\rightarrow$ qum bi tasğīl al-ḥurūğ, aw taḥwīl al-mustahndim, aw qafl al-šāša aw īqāftašğīl al-ḥāsūb

\section{Закључак}

Арапски се сматра једним од најтежих језика за локализацију (Yassin), када говоримо о великим светским језицима, чија тржишта су посебно занимљива произвођачима софтвера. Разлози за то су многобројни - од специфичности арапске граматике, писма и језика, преко културних образаца и менталитета арапског народа широм арапског света, до недостатка и неуједначености компјутерске терминологије на арапском говорном подручју. Иако се локализација 
на арапски раније вршила ad hoc, без строго утврђених правила (Yassin), методологија арабизације софтвера се све више изграђује, а иновације и промене у овој индустрији настају свакодневно. Због тога, све што смо рекли у овом раду може врло брзо да застари.

Данас арабизовани софтвер није реткост, али још увек смо далеко од тога да употреба арапског језика у свету буде пропорционална употреби овог језика у софтверским производима. Стога ће локализација софтвера на арапски у будућности несумњиво представљати важан задатак и озбиљан подвиг за лингвисте и арабисте.

\section{Литература}

Bernal-Merino, Miguel Á. Translation and Localisation in Video Games: Making Entertainment Software Global. Routledge, 2015.

Brooks, David. "What Price Globalization? Managing Costs at Microsoft." Translating Into Success: Cutting-edge Strategies for Going Multilingual in a Global Age. Eds Robert C. Sprung and Simone Jaroniec. Amsterdam/Philadelphia: John Benjamins Publishing Company, 2000. 43-58.

Corbolante, Licia, and Ulrike Irmler. "Software Terminology and Localization." Handbook of Terminology Management, Volume 2: Application-Oriented Terminology Management. Eds Sue Ellen Wright and Gerhard Budin. Amsterdam/Philadelphia: John Benjamins Publishing Company, 1997. 516-538.

DiFranco, Carla. "Localization Cost". Perspectives on Localization. Ed. Keiran J. Dunne. Amsterdam/Philadelphia: John Benjamins Publishing Company, 2006. 47-68.

Esselink, Bert. A Practical Guide to Localization. Amsterdam/Philadelphia: John Benjamins Publishing Company, 2000.

Jiménez-Crespo, Miguel A. Translation and Web Localization. Routledge, 2013.

Maxwell Chandler, Heather, and Stephanie O'Malley Deming. The Game Localization Handbook. Jones \& Bartlett Learning, 2012.

Mazur, Iwona. "The Metalanguage of Localization: Theory and Practice". The Metalanguage of Translation. Eds Yves Gambier and Luc van Doorslaer. Amsterdam/Philadelphia: John Benjamins Publishing Company, 2009. 145-166.

Microsoft. "Arabic Style Guide". Web. Dec 302015 <file:///C:/Users/USER/Downloads/ ara-sau-styleguide.pdf>

Pym, Anthony. The Moving Text: Localization, Translation, and Distribution. Amsterdam/ Philadelphia: John Benjamins Publishing Company, 2004.

Schäler, Reinhard. "Linguistic resources and localisation". Topics in Language Resources for Translation and Localisation. Ed. Elia Yuste Rodrigo. Amsterdam/Philadelphia: John Benjamins Publishing Company, 2008. 195-214. 
Singh, Nitish. Localization Strategies for Global E-Business. Cambridge University Press, 2012.

Sin-Wai, Chan. "Approaching localization". The Routledge Handbook of Translation Studies. Eds Carmen Millán and Francesca Bartrina. Routledge, 2013. 347-362.

Yassin, Yehia A. Why Arabic Is the Most Difficult Language for Localization. Web. 30 Dec 2015 <http://www.translationdirectory.com/article460.htm>

Yunker, John. Beyond Borders: Web Globalization Strategies. New Riders Publishing, 2003.

\section{Извори}

Arabeyes. Web. Dec 302015 <http://www.arabeyes.org>

Facebook"ArabicStyleGuideforCommunity".Web.Dec302015<https://fbcdn-dragon-a.akamaihd. net/hphotos-ak-xtp1/t39.2365-6/10173493_1424629954491499_1711124792_n. pdf>

Hootsuite Translation Project. Web. Dec 302015 <https://translate.hootsuite.com>

Microsoft. "Translations in Localized Microsoft Products". Web. Dec 302015 <https:// www.microsoft.com/Language>

Transifex Localization Platform. Web. Dec 302015 <https://www.transifex.com>

Ivana Mali

University of Belgrade

Faculty of Philology

\section{SOME PROBLEMS OF SOFTWARE LOCALIZATION INTO ARABIC}

\section{Summary}

The term localization refers to the adaptation of some product to the specific market. This paper addresses the localization of software products for the Arab states. The localization process is not only about translating software discourse into Arabic, but it also includes a certain level of technical and cultural adaptation. This paper analyzes some characteristics of the Arabic language and culture, which come into play during the localization process.

Key words: Arabic Language, Software Localization, Translation, Software Terminology, Arab Culture, Arabic Script 